\section{Sexual satisfaction in couples in the male and female climacteric stage}

\author{
Satisfacción sexual en parejas durante el climaterio \\ femenino y masculino
}

\author{
Satisfação sexual nos casais durante o climatério \\ feminino e masculino
}

\author{
${ }_{1}$ Universidad de Concepción, \\ Concepción, Chile. \\ 2 Universidad Católica del \\ Norte, Antofagasta, Chile. \\ Correspondence \\ A. Salazar-Molina \\ Universidad de Concepción. \\ Casilla 160C, Concepción \\ 4030000, Chile. \\ alide.alisalaz@gmail.com
}

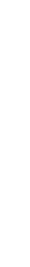

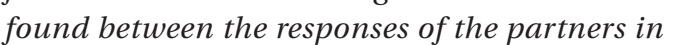
relation to satisfaction with their sexual life. Moreover, a slight degree of agreement was found between the sexual life satisfaction reported by women and their partners' perceptions of the women's sexual life satisfaction. Additionally, a slight degree of agreement was reported between the sexual life satisfaction reported by men and their partners' perceptions of the men's sexual life satisfaction. This study provides new information about Chilean couples in the climacteric stage in relation to self-reported sexual satisfaction and perceived satisfaction in couples.

Sexual Health; Climateric; Menopause; Andropause
The objective was to describe the sexual life sat-
isfaction of couples in the climacteric stage and determine whether there are differences between the perception of satisfaction and the sex life of each partner. We studied 142 couples obtained by stratified sampling of family health centers,
Concepción, Chile. $66 \%$ of women and $84 \%$ of

Alide Salazar-Molina 1 Tatiana Paravic Klijn 1

\section{Resumen}

El estudio describe la satisfacción con la vida sexual de parejas en etapa de climaterio, además de determinar si existen diferencias entre las percepciones de satisfacción con la vida sexual de cada miembro de la pareja. Se estudiaron 142 parejas, obtenidas mediante muestreo estratificado en centros de salud familiar de Concepción, Chile. Un 66\% de mujeres y un $84 \%$ de hombres informaron sentirse muy o algo satisfechos con su vida sexual de pareja. Se encontró una concordancia leve entre las respuestas de cada miembro de la pareja, en relación con la satisfacción en la vida sexual. También, se encontró un grado de acuerdo leve entre satisfacción con la vida sexual informada por la mujer y la percepción de satisfacción con la vida sexual que su pareja tiene de ella. Asimismo, se reportó un grado discreto de acuerdo para la satisfacción con vida sexual referida por el hombre y la percepción de satisfacción con la vida sexual que su pareja tiene de él. Este estudio proporciona nueva información respecto a parejas chilenas en etapa de climaterio, en relación con la satisfacción sexual autoinformada y percibida en la pareja.

Salud Sexual; Climaterio; Menopausia; Andropausia 


\section{Introduction}

Many researchers have shown interest in investigating sexual satisfaction, producing a wide variety of studies related to this subject in different groups of individuals $1,2,3,4,5,6,7,8,9,10$. However, estimations of satisfaction carried out in population samples vary considerably, producing inconclusive results about the differences in levels of sexual satisfaction in women and men ${ }^{3}$.

Moreover, in recent years, the study of the sexual satisfaction of women during the climacteric stage has received increasing attention 11,12,13,14. In contrast, sexual satisfaction in men during andropause has been underinvestigated, especially in developed countries 15 .

Few studies have been published on this topic in a context of couples in Latin America. In Chile, there are no studies on sexual satisfaction in couples during the climacteric stage. Only a few previous studies have examined sexual satisfaction at other moments in life focused on the individual perspective 6 or using a dyadic perspective ?

Moreover, despite the contributions researchers have made to the study of sexuality in this area, research has tended to focus on individuals, in spite of the obviously dyadic nature of sexual experiences between couples 16,17.

Only a small number of researchers have focused on satisfaction in the context of couples during the climacteric stage $15,18,19,20$, in circumstances where there is evidence of a significant relationship between sexual satisfaction and general satisfaction with the relationship 2,21,22. As it has been reported that sexual satisfaction is linked to the stability of the union, sexual satisfaction within the couple is an important issue to explore $5,6,15,17,23$. Thus, the study by Heiman et al. 20 with 400 middle-aged couples showed that the average levels of satisfaction were quite high for both women and men. As in previous studies, these researchers reported that sexual satisfaction and relationship satisfaction were significantly correlated.

In addition, it has been reported that the impact of a happy and fulfilling sexual relationship on the lives of both partners is a factor that has been shown to have a significant effect on other areas of their lives 24, as the results of the Sexual Health and Overall Wellness Survey (SHOW) recently pointed out 25 . This survey indicates that higher levels of satisfaction with sex are strongly associated with higher levels of satisfaction with other important aspects of life and overall physical health, family life, and economic well-being in men and women. Additionally, relationship factors have also been shown to have an impact on the perception of the quality of sexual life in meno- pausal women, exceeding the effects of menopausal status and symptoms 26,27.

Thus, the aim of this study was to describe couples' satisfaction with their sex life in the climacteric stage and determine whether there are differences between each partner's perceptions of the other partner's satisfaction with their sex life.

\section{Subjects and methods}

The study was cross-sectional and correlational. It was carried out in the city of Concepción in south-central Chile. There are eight health centers in Concepción, six municipal centers that attend to $72 \%$ of the population and two centers that depend on the health service and another service (attending to 28\%). In this study, we consider the six centers that have the same municipal dependence and that attend to the majority of the population who are beneficiaries of FONASA (National Health Fund).

The female population from 40 to 60 years old who were registered and validated in the municipal health centers of Concepción as having an up-to-date Papanicolaou (PAP) test was 12,833. This criterion was used in order to access women who were registered and validated in the health center with a reliable age and address; at the time of the study, the health centers did not have a database with which to perform a selection by sex and age.

Considering this information, a stratified sampling was carried out, with the six health centers as each stratus. The sample size was calculated for the variable quality of life, considering a confidence level of $95 \%$ and a standard error of 0.35 units. The result was an "n" greater than or equal to 140 couples, so that a sample of 142 couples was gathered. The sample was proportional to the size of each stratus.

To do so, a selection was randomly made from the PAP registers of each of the six centers. After that, a visit was made to the home to verify the existence of a couple between 45 and 60 years old, and their willingness to participate in the study.

Participation criteria were: women from 40 to 60 years old and users of public health centers in the city of Concepción; having a health status consistent with performing routine activities; not being on medical leave at the time of the questionnaire; and having given their informed consent to participate in the research. The group of men included partners of women who met the study criteria and agreed to participate: men between 40 and 65 years old; with a legal or consensual bond and a health status in concordance with their routine activities; not on medical leave at the time 
of the questionnaire; and having given informed consent to participate in the research. The aforementioned ages were considered based on a review of the literature $28,29,30$.

\section{Measures}

The measures included a set of socio-demographic variables, such as age, education, number of children, employment status, income, marital status, and duration of relationship. In addition, we included information about the health system (FONASA or ISAPRE - Private Pension Health Institution), diagnosed diseases, and use of medicines. A detailed description of the variables is available on request.

This variable satisfaction with the couple's sexual life was measured by the question: "How satisfied are you with your sex life as a couple?". This question was posed based on the questions contained in the Female Sexual Function Index (FSFI) 31 and the Brief Male Sexual Function Inventory ${ }^{32}$. This measure has 5 response alternatives (from 1 = very satisfied to $5=$ very dissatisfied). Additionally, to find out the perceptions of each member of the couple about their partner's satisfaction with their sexual life, they were asked, using the same response scale: "How satisfied is your partner with his/her sexual life?".

\section{Procedure}

The semi-structured questionnaires were completed face-to face at the couple's home simultaneously by two different interviewers in separate rooms: a female interviewer who questioned the woman and a male interviewer who questioned the man. Interviewees were asked not to make comments or ask their partners questions during the interview, and they were assured that their responses would be confidential and that their partners would not find out their answers. Each participant was interviewed for 30 minutes, corresponding to the average length of the interview in women (40 minutes) and in men (20 minutes), where other instruments were applied.

The percentage of general rejection was $23 \%$. Regarding this point, in general, the women were more willing to participate. The most frequent difficulty found with the men was the impossibility of interviewing them due to work outside the city or complicated time schedules.

This study was approved by the Ethics Committee of the Faculty of Medicine at the University of Concepción. Its development was subsequently authorized by the Department of Health of Concepción and the directors of each health center.

\section{Analysis}

For the statistical analysis, the data were processed using SPSS 15.0 (SPSS Inc., Chicago, USA). Descriptive statistics and the kappa index were used. The results were interpreted according to the classification proposed by Landis \& Koch 33, considering kappa values below 0 as a poor degree of agreement, between 0 and 0.20 as slight, 0.21 and 0.40 as fair, between 0.41 and 0.60 as moderate, between 0.61 and 0.80 as substantial, and between 0.81 and 1 as almost perfect. Statistical significance was considered at $\mathrm{p}<0.05$.

\section{Results}

Table 1 shows the socio-demographic characteristics of the members of the study. Thus, $86.6 \%$ of women $(\mathrm{M}=49.1$ years old; $\mathrm{SD}=5.8)$ and $85.9 \%$ of men $(\mathrm{M}=51.5$ years old; $\mathrm{SD}=6.8)$ reported being married for an average of 24.6 years in women and 24.4 years in men. Regarding education, $28.9 \%$ of women and $44.3 \%$ of men reported having completed secondary education. In relation to their income, most of the men $(68.2 \%)$ received an income of over USD 364, while only $17.6 \%$ of the women received a similar income.

Most of the participants reported being beneficiaries of the FONASA, the country's public health system. A higher percentage of women presented diseases than the men. The most common disorders, classified by cause group for both sexes, were diseases of the circulatory system, endocrine, nutritional and metabolic diseases, and diseases of the musculoskeletal system and connective tissue. Regarding medicine consumption, $52.1 \%$ of the women took medication, and 35.2 of the men did so. Almost half of the women had gone through menopause, and of them, only $2.8 \%$ were undergoing hormone replacement therapy (HRT).

Table 2 shows the results of the variables related to sexual life satisfaction and the perception of their partner's satisfaction with his/her sexual life.

Thus, $66.1 \%$ of the women reported feeling very or moderately satisfied with their sex lives, and $18.6 \%$ reported feeling moderately or very dissatisfied. Regarding the perception of their partner's satisfaction with the couple's sexual life, $69 \%$ of the women felt that their partner was very or moderately satisfied, and $21.1 \%$ felt that their partner was moderately or very dissatisfied.

In the case of the men, $83.8 \%$ reported feeling very or moderately satisfied with their sex lives, and $5.6 \%$ moderately or very dissatisfied. Regarding their perception of their partner's satisfaction with the couple's sexual life, $78.9 \%$ of the men perceived that their partners were very or moderately 
Table 1

Sociodemographic characteristics of the couples in the study and other relevant variables ( $N=142$ couples).

\begin{tabular}{|c|c|c|c|c|}
\hline \multirow[t]{2}{*}{ Variables } & \multicolumn{2}{|c|}{ Women $(N=142)$} & \multicolumn{2}{|c|}{ Men $(N=142)$} \\
\hline & n & $\%$ & $\mathrm{n}=142$ & $\%$ \\
\hline \multicolumn{5}{|l|}{ Age range (years) } \\
\hline Younger than 44 & 37 & 26.1 & 26 & 18.4 \\
\hline $45-49$ & 33 & 23.2 & 30 & 21.3 \\
\hline $50-54$ & 43 & 30.3 & 33 & 23.4 \\
\hline $55-60$ & 29 & 20.4 & 38 & 27.0 \\
\hline Older than 60 & 0 & 0.0 & 14 & 9.9 \\
\hline \multicolumn{5}{|l|}{ Marital status * } \\
\hline Single & 0 & 0.0 & 0 & 0.0 \\
\hline Married & 123 & 86.6 & 122 & 85.9 \\
\hline Living together & 14 & 9.8 & 12 & 8.5 \\
\hline Separated & 3 & 2.1 & 7 & 4.9 \\
\hline Other (widower, annulled) & 2 & 1.4 & 1 & 0.7 \\
\hline \multicolumn{5}{|l|}{ Education } \\
\hline No schooling & 1 & 0.7 & 0 & 0.0 \\
\hline Incomplete basic studies & 23 & 16.2 & 12 & 8.5 \\
\hline Complete basic studies & 19 & 13.4 & 17 & 12. 0 \\
\hline Incomplete High School & 28 & 19.7 & 32 & 22.5 \\
\hline Complete High School & 41 & 28.9 & 63 & 44.3 \\
\hline Technical & 23 & 16.2 & 7 & 4.9 \\
\hline University & 7 & 4.9 & 11 & 7.7 \\
\hline \multicolumn{5}{|l|}{ Children } \\
\hline$\leq 2$ & 69 & 48.6 & 63 & 44.4 \\
\hline $3-4$ & 59 & 41.5 & 60 & 42.3 \\
\hline$\geq 5$ & 10 & 7.0 & 14 & 9.9 \\
\hline No & 4 & 2.8 & 5 & 3.5 \\
\hline \multicolumn{5}{|l|}{ Work } \\
\hline Employed & 63 & 44.3 & 128 & 90.1 \\
\hline Unemployed & 9 & 6.3 & 3 & 2.1 \\
\hline Inactive & 70 & 49.2 & 11 & 7.7 \\
\hline \multicolumn{5}{|l|}{ Income average in pesos $(\$) \star \star$} \\
\hline No income & 69 & 48.6 & 4 & 2.8 \\
\hline$\leq 200,000$ & 47 & 33.1 & 41 & 28.8 \\
\hline Between 200,001 and 350,000 & 18 & 12.7 & 57 & 40.1 \\
\hline Between 350,001 and 600,000 & 5 & 3.5 & 26 & 18.3 \\
\hline$\geq 600.000$ & 2 & 1.4 & 14 & 9.8 \\
\hline \multicolumn{5}{|l|}{ Health system } \\
\hline FONASA & 140 & 98.8 & 120 & 84.5 \\
\hline ISAPRE & - & - & 3 & 2.1 \\
\hline No health system & 2 & 1.4 & 15 & 10.6 \\
\hline Other & - & - & 4 & 2.8 \\
\hline Diagnosed disease & 85 & 59.9 & 68 & 47.9 \\
\hline Using drugs & 74 & 52.1 & 50 & 35.2 \\
\hline Pre menopause & 75 & 52.8 & - & - \\
\hline Post menopause & 67 & 47.2 & - & - \\
\hline Use of hormone replacement therapy & 4 & 2.8 & - & - \\
\hline Using hormonal birth control & 16 & 11.3 & - & \\
\hline
\end{tabular}

* All women living with a partner;

** 1 USD $=550$ Chilean pesos.

Note: the numbers in the columns do not always add up to the same totals because of missing responses on some questions 
Sexual life satisfaction in couples ( $N=142$ couples).

\begin{tabular}{|c|c|c|c|c|}
\hline \multirow[t]{2}{*}{ Variable } & \multicolumn{2}{|c|}{ Women } & \multicolumn{2}{|c|}{ Men } \\
\hline & $f$ & $\%$ & $f$ & $\%$ \\
\hline \multicolumn{5}{|l|}{ Satisfaction with sexual life in couples } \\
\hline Very satisfied & 64 & 45.0 & 79 & 55.6 \\
\hline Moderately satisfied & 30 & 21.1 & 40 & 28.2 \\
\hline About equally satisfied and dissatisfied & 22 & 15.5 & 15 & 10.6 \\
\hline Moderately dissatisfied & 14 & 9.9 & 5 & 3.5 \\
\hline Very dissatisfied & 12 & 8.5 & 3 & 2.1 \\
\hline \multicolumn{5}{|c|}{ Perceived satisfaction with their partner's sexual life } \\
\hline Very satisfied & 63 & 44.4 & 66 & 46.5 \\
\hline Moderately satisfied & 35 & 24.6 & 46 & 32.4 \\
\hline About equally satisfied and dissatisfied & 11 & 7.7 & 20 & 14.1 \\
\hline Moderately dissatisfied & 21 & 14.8 & 6 & 4.2 \\
\hline Very dissatisfied & 9 & 6.3 & 2 & 1.4 \\
\hline Did not say & 2 & 1.4 & 2 & 1.4 \\
\hline Did not answer & 1 & 0.7 & - & - \\
\hline
\end{tabular}

satisfied and only $2.8 \%$ perceived that their partners were moderately or very dissatisfied.

As Table 2 reveals, women's and men's answers to the question: "How satisfied is your partner, in general terms, with his/her sex life?", show a difference of up to $11 \%$ compared to their responses to the question: "How satisfied are you, in general terms, with your sex life?". On this topic, men overestimated the level of satisfaction of their partners, while women underestimated the level of satisfaction of their partners.

Table 3 shows the correlation between the answers reported by each of the partners about their sexual life satisfaction. The answers were analyzed using the kappa index. The kappa index value was $0.188(\mathrm{p}=0.000)$, which indicated a slight agreement between the men's and women's answers.

Results in Tables 4 and 5 show the correlation between the sexual life satisfaction reported by each individual and the sexual life satisfaction perceived by his/her partner. There was a slight degree of agreement $(k a p p a=0.161 ; p=0.001)$ between the sexual life satisfaction reported by women and their partners' perceptions of the women's sexual life satisfaction, and mild agreement $(\mathrm{kappa}=0.229, \mathrm{p}=0.000$ ) between the sexual life satisfaction reported by men and the partners' perception of the men's sexual life satisfaction.

\section{Discussion}

Few studies have measured sexual life satisfaction focused on adult couples 17 .

Regarding satisfaction with their sex lives, more than half of the investigated women reported feeling very or moderately satisfied; regarding dissatisfaction, the percentage of women with some level of dissatisfaction was more than triple that of men. Along these lines, lower and higher percentages of satisfaction have been reported by other researchers 10,18,34. For example, a study performed on 47 married couples with women from 48 to 53 years old showed that only $43 \%$ of the women stated that they were satisfied 18 . Similarly, the results of the Global Better Sex Survey, conducted in 6,291 women from 27 countries (50\% over 40 years old), showed that $58 \%$ of respondents were not fully satisfied with their sex lives 10 . However, higher percentages have also been reported. For example, a study of 1,002 French people (483 men and 519 women) aged 35 and over showed that $83 \%$ of women expressed relative or full satisfaction with their sex lives, and $37.9 \%$ reported full satisfaction 34 .

Regarding dissatisfaction, research conducted in women with partners reported rates of dissatisfaction that were a little higher than those found in the present study: $21.4 \%$ in Colombian women from 40 to 62 years old $35,23 \%$ in women from the U.S. from 50 to 79 years old 11, and $25.7 \%$ in Brazilian women from 45 to 60 years old 36 . 
Cross-tabulation of sexual life satisfaction in women and men ( $N=142$ couples).

\begin{tabular}{|c|c|c|c|c|c|c|}
\hline & \multicolumn{5}{|c|}{ Sexual life satisfaction in men } & \multirow[t]{2}{*}{ Total } \\
\hline & $\begin{array}{c}\text { Very } \\
\text { satisfied }\end{array}$ & $\begin{array}{c}\text { Moderately } \\
\text { satisfied }\end{array}$ & $\begin{array}{c}\text { About } \\
\text { equally } \\
\text { dissatisfied } \\
\text { and satisfied }\end{array}$ & $\begin{array}{l}\text { Moderately } \\
\text { dissatisfied }\end{array}$ & $\begin{array}{c}\text { Very } \\
\text { dissatisfied }\end{array}$ & \\
\hline \multicolumn{7}{|l|}{ Sexual life satisfaction in women } \\
\hline Very satisfied & 46 & 14 & 2 & 2 & 0 & 64 \\
\hline Moderately satisfied & 17 & 10 & 2 & 1 & 0 & 30 \\
\hline About equally satisfied and dissatisfied & 7 & 7 & 6 & 1 & 1 & 22 \\
\hline Moderately dissatisfied & 4 & 5 & 4 & 1 & 0 & 14 \\
\hline Very dissatisfied & 5 & 4 & 1 & 0 & 2 & 12 \\
\hline Total & 79 & 40 & 15 & 5 & 3 & 142 \\
\hline
\end{tabular}

kappa $=0,188 ; p=0,000$

Cross-tabulation of sexual life satisfaction in women's and men's perceptions of their partner's sexual life satisfaction $(\mathrm{N}=140$ couples $)$ *

\begin{tabular}{|c|c|c|c|c|c|c|}
\hline & \multicolumn{5}{|c|}{ Men's perception of their partner's sexual life satisfaction. } & \multirow[t]{2}{*}{ Total } \\
\hline & $\begin{array}{c}\text { Very } \\
\text { satisfied }\end{array}$ & $\begin{array}{l}\text { Moderately } \\
\text { satisfied }\end{array}$ & $\begin{array}{c}\text { About } \\
\text { equally } \\
\text { satisfied and } \\
\text { dissatisfied }\end{array}$ & $\begin{array}{l}\text { Moderately } \\
\text { dissatisfied }\end{array}$ & $\begin{array}{c}\text { Very } \\
\text { dissatisfied }\end{array}$ & \\
\hline \multicolumn{7}{|l|}{ Sexual life satisfaction in women } \\
\hline Very satisfied & 41 & 19 & 2 & 2 & 0 & 64 \\
\hline Moderately satisfied & 14 & 12 & 2 & 1 & 0 & 29 \\
\hline About equally satisfied and dissatisfied & 8 & 5 & 5 & 2 & 1 & 21 \\
\hline Moderately dissatisfied & 1 & 5 & 8 & 0 & 0 & 14 \\
\hline Very dissatisfied & 2 & 5 & 3 & 1 & 1 & 12 \\
\hline Total & 66 & 46 & 20 & 6 & 2 & 140 \\
\hline
\end{tabular}

kappa $=0,161 ; p=0,001$.

* $N=140$ due to missing information for the variable.

However, in a greater proportion than women, men reported feeling very or moderately satisfied with their sexual lives, and a much lower percentage reported feeling moderately or very dissatisfied. This finding is consistent with those from previous studies 18,34. For example, Colson et al. 34, in a representative sample of 519 French men aged 35 and older, reported that $83.2 \%$ of the subjects expressed relative or full satisfaction with their sex lives, and $33.1 \%$ reported full satisfaction. However, previous research has shown lower figures than those reported in this study, such as the $E u$ ropean Male Ageing Study, where 57\% and 60\% of subjects from 40 to 49 and 50 to 59 years old, respectively, stated that they were satisfied with their sexual lives 37. In addition, the Global Better Sex Survey, conducted in 6,272 men from 27 countries (50\% over 40 years old), reported that $57 \%$ of respondents were not completely satisfied with their sex lives 10, and the Global Better Sex Survey in Asia, carried out with 1,776 men from 8 Asian countries, found that $40 \%$ of subjects from 40 to 59 years old reported being moderately satisfied with their sex lives, while $36 \%$ reported being indifferent or dissatisfied 38. 
Cross-tabulation of sexual life satisfaction in men's and women's perceptions of their partner's sexual life satisfaction $(\mathrm{N}=139$ couples $)$ *.

\begin{tabular}{|c|c|c|c|c|c|c|}
\hline & \multicolumn{5}{|c|}{ Women's perception of their partner's sexual life satisfaction } & \multirow[t]{2}{*}{ Total } \\
\hline & $\begin{array}{c}\text { Very } \\
\text { satisfied }\end{array}$ & $\begin{array}{l}\text { Moderately } \\
\text { satisfied }\end{array}$ & $\begin{array}{c}\text { About } \\
\text { equally } \\
\text { satisfied and } \\
\text { dissatisfied }\end{array}$ & $\begin{array}{l}\text { Moderately } \\
\text { dissatisfied }\end{array}$ & $\begin{array}{c}\text { Very } \\
\text { dissatisfied }\end{array}$ & \\
\hline \multicolumn{7}{|l|}{ Sexual life satisfaction in men } \\
\hline Very satisfied & 46 & 18 & 5 & 5 & 3 & 77 \\
\hline Moderately satisfied & 13 & 14 & 2 & 7 & 3 & 39 \\
\hline About equally satisfied and dissatisfied & 1 & 3 & 4 & 6 & 1 & 15 \\
\hline Moderately dissatisfied & 3 & 0 & 0 & 2 & 0 & 5 \\
\hline Very dissatisfied & 0 & 0 & 0 & 1 & 2 & 3 \\
\hline Total & 63 & 35 & 11 & 21 & 9 & 139 \\
\hline
\end{tabular}

kappa $=0,229 ; p=0,000$.

* $N=139$ due to missing information for the variable.

Moreover, the rates of sexual satisfaction reported in the present study show that women have lower levels of sexual satisfaction than men. This result confirms previous studies in which heterosexual women in late middle age reported markedly lower levels of sexual satisfaction than heterosexual men ${ }^{15}$. Nevertheless, there is evidence that married couples are generally sexually satisfied 39 .

With regard to the perception of their partner's satisfaction with the couple's sex life, women underestimated the level of satisfaction of their partners. Just over two thirds (69\%) of the women felt that their partners were very or moderately satisfied, while a higher percentage of men (84\%) said they were. The fact that women underestimated their partners' level of satisfaction may be based on women's self-confidence or other psychological factors. Meanwhile, men overestimated the women's level of satisfaction because almost eighty percent of them perceived that their partners were very or moderately satisfied, when in reality the percentage $(66 \%)$ was lower. This finding may reflect the nature of Chilean men, as sexual satisfaction is considered an indicator of male power and virility 6 .

Other studies have investigated whether the respondents thought their partners were satisfied with their sex lives. Results show that $80.4 \%$ of subjects (45-64 years old) thought their partners were satisfied, a higher percentage than the level of satisfaction reported by the respondents themselves ${ }^{3}$. The trend observed in the study by Dunn et al. 3 is similar, except in the case of the women, who perceived that their partners were equally as satisfied as they were. On this point, other studies have shown that women perceive the sexual gratification of their husbands with much more precision than husbands perceive their wives' satisfaction 18

Levels of slight and mild agreement can be interpreted as insignificant and low, respectively. In this regard, the levels of agreement found by comparing the responses of partners may reflect a lack of communication between partners in sexual relationships 3 , as it has been documented that the different ways men and women feel sexually satisfied indicate the importance of couples' communication about their sexual needs and desires 2,40. Thus, in the degree of coherence in the couple's sexual needs and expectations, their communication capabilities, among other factors, are critical components of marital and sexual adjustment and overall satisfaction with the relationship 41 ; therefore, future studies should include the measurement of these variables.

Furthermore, as stated previously, a link is suggested between sexual satisfaction and marital communication in general 42 . In fact, today many sex therapists recommend "talking to your partner" as one of the main components of treatment and as an educational element 43,44. Furthermore, longitudinal studies, such as the Prevention and Relationship Enhancement Program (PREP) 45, found that sexual satisfaction improved as the result of a program mainly based on communication skills for couples.

Therefore, it seems that the expression of sexual needs and desires might predict sexual satisfac- 
tion in two ways: (a) by increasing the chances of actually having one's sexual needs satisfied and (b) by increasing emotional closeness 40 .

In conclusion, nearly two-thirds of the women referred to feeling very or somewhat satisfied with their sex life as a couple, and around $84 \%$ of the men said they felt very or somewhat satisfied. Regarding the perception of the partner's satisfaction with their sex life, the women's responses weakly agreed with the men's responses.

Some limitations of this study are that the data were obtained from a relatively small sample of couples who came from an urban area of the country and mainly from the middle class. This means that couples in rural communities and beneficiaries of private health services may show a different pattern of results, so that the generalizability of the findings is limited 17. A second limitation of the study is linked to the use of a single item to measure sexual satisfaction. Psychometric theory has long noted that single-item scales are much less reliable than multi-item scales and that, in a study with too many items, prediction is imprecise. Thus, an important limitation in this study is the way we assessed sexual satisfaction. Future studies must be developed with focus on a suitable evaluation of sexual satisfaction, generating valid and reliable instruments 46 . This research was a cross-sectional study. Therefore, future longitudinal studies should be conducted to confirm these findings. A third limitation is related to health measures. Previous studies indicate that menopausal symptoms predicted variance in different aspects of sexual satisfaction 13 . Considering that this is a population with different health problems, future studies should analyze the effects of these variables on the sexual life satisfaction of the couple.

Another limitation was the difficulty of locating the selected subjects, due to the large number of unknown addresses, despite the exclusion of the beneficiaries who lived outside the sector, and the complexity of simultaneously finding both members of the couple at home, which at times required more than one visit for an interview, depending on the availability of both individuals.

Finally, knowledge about the sexual satisfaction of women and men during the climacteric stage from an individual and couples perspective will provide tools that could help to remove stereotypes and strengthen the relationship between couples and mutual self-care, with important implications for the health of the couple and the family ${ }^{47}$. There is evidence that the greater the satisfaction reported by a couple in their sexual relationships, the smoother their adaptation is to the changes that occur during middle age, leading to better reported health and health behavior 18 .

Moreover, the present study may provide new information about Chilean couples in the climacteric stage in relation to self-reported sexual satisfaction and perceived satisfaction in couples. Furthermore, the difference in partners' perceptions is also revealed; further research will have to explain and elucidate the causes and effects of the reported findings.

\section{Resumo}

O objetivo foi descrever a satisfação com a vida sexual dos casais no período do climatério e determinar se existem diferenças entre as percepções da satisfação com a vida sexual de cada membro do casal. Foram seleccionados cento e quarenta e dois casais por meio de uma amostragem estratificada dos centros de saúde familiar em Concepción, Chile. Sessenta e seis porcento das mulheres e $84 \%$ dos homens relataram ser muito ou moderadamente satisfeitos com suas vidas sexuais. Verificou-se uma leve concordância entre as respostas de cada membro do casal em relação à satisfação com a vida sexual. Também identificou-se um leve grau de concordância entre a satisfação com a vida sexual referida pela mulher e a percepção da satisfação com a vida sexual que seu parceiro tem dela. Da mesma forma, verificou-se um discreto grau de acordo para a referida pelo homem e a percepção da satisfação com a vida sexual que sua companheira tem dele. É oferecida uma nova informação a respeito dos casais chilenos no período do climatério, em relação à satisfação sexual autoinformada e a satisfação percebida no parceiro, evidenciando-se a diferença da percepção entre os casais.

Saúde Sexual; Climatério; Menopausa; Andropausa 


\section{Contributors}

A. Salazar-Molina and T. P. Klijn contributed on the conception and design of the work, analysis and interpretation of data, drafting the article and revising it critically for important intellectual content and on the final approval of the version to be published. J. B. Delgado collaborated on the drafting the article and revising it critically for important intellectual content and final approval of the version to be published.

\section{References}

1. Laumann EO, Gagnon JH, Michael RT, Michaels S The social organization of sexuality: Sexual practices in the United States. Chicago: University of Chicago Press; 1994.

2. Haavio-Manila E, Kontula O. Correlates of increased sexual satisfaction. Arch Sex Behav 1997; 26:399-419.

3. Dunn KM, Croft PR, Hackett GI. Satisfaction in the sex life of a general population sample. J Sex Marital Ther 2000; 26:141-51.

4. Yela C. Predictors of and factors related to loving and sexual satisfaction for men and women. Eur Rev Appl Psychol 2000; 50:235-43.

5. Richters J, Grulich AE, de Visser RO, Smith AMA, Rissel CE. Sex in Australia: sexual and emotional satisfaction in regular relationships and preferred frequency of sex among a representative sample of adults. Aust N Z J Public Health 2003; 27:171-9.

6. Barrientos JE, Páez D. Psychosocial variables of sexual satisfaction in Chile. J Sex Marital Ther 2006; 32:351-68.

7. Heresi Milad E, Rivera Ottenberger D, Huepe Artigas D. Associations among attachment, sexuality, and marital satisfaction in adult Chilean couples: a linear hierarchical models analysis. J Sex Marital Ther 2014; 40:259-74.

8. Byers ES, MacNeil Sh. Further Validation of the interpersonal exchange model of sexual satisfaction. J Sex Marital Ther 2006; 32:53-69.

\section{Acknowledgments}

Doctoral Thesis Grants Research: CONICYT, Chile; Vicerreitoria de Investigación y Desarrollo (proyecto: 209.082.041-0).
9. Parish WL, Luo Y, Stolzenberg R, Laumann EO, Farrer G, Pan S. Sexual practices and sexual satisfaction: a population based study of Chinese urban adults. Arch Sex Behav 2007; 36:5-20.

10. Mulhall J, King R, Glina S, Hvidsten K. Importance of and satisfaction with sex among men and women worldwide: results of the Global Better Sex Survey. J Sex Med 2008; 5:788-95.

11. Howard JR, O'Neil S, Travers C. Factors affecting sexuality in older Australian women: sexual interest, sexual arousal, relationships and sexual distress in older Australian women. Climacteric 2006; 9:355-67.

12. McCall-Hosenfeld JS, Jaramillo SA, Legault C, Freund KM, Cochrane BB, Manson JE, et al. Correlates of sexual satisfaction among sexually active postmenopausal women in the Women's Health Initiative-Observational Study. J Gen Intern Med 2008; 23:2000-9.

13. Dundon CM, Rellini AH. More than sexual function: predictors of sexual satisfaction in a sample of women age 40-70. J Sex Med 2010; 7:896-904.

14. Woloski-Wruble AC, Oliel Y, Leefsma M, HochnerCelnikier D. Sexual activities, sexual and life satisfaction, and successful aging in women. J Sex Med 2010; 7:2401-10.

15. Carpenter L, Nathanson C, Young JK. Physical women, emotional men: gender and sexual satisfaction in midlife. Arch Sex Behav 2009; 38:87-107. 
16. DeLamater J, Hyde JS. Conceptual and theoretical issues in studying sexuality in close relationships. In: Harvey JH, Wenzel A, Sprecher S, editors. The handbook of sexuality in close relationships. Hillsdale: Erlbaum; 2004. p. 7-30.

17. Butzer B, Campbell L. Adult attachment, sexual satisfaction, and relationship satisfaction: A study of married couples. Pers Relatsh 2008; 15:141-54.

18. Walfisch S, Maoz B, Antonovsky H. Sexual satisfaction among middle-aged couples: correlation with frequency of intercourse and health status. Maturitas 1984; 6:285-96.

19. Yeh HC, Lorenz FO, Wickrama KA, Conger RD, Elder Jr. GH. Relationships among sexual satisfaction, marital quality, and marital instability at midlife. J Fam Psychol 2006; 20:339-43.

20. Heiman JR, Long JS, Smith SN, Fisher WA, Sand MS, Rosen RC. Sexual satisfaction and relationship happiness in midlife and older couples in five countries. Arch Sex Behav 2011; 40:741-53.

21. Henderson-King DH, Veroff J. Sexual satisfaction and marital well-being in the first years of marriages. J Soc Pers Relat 1994; 11:509-34.

22. Byers ES. Relationship satisfaction and sexual satisfaction: a longitudinal study of individuals in long-term relationships. J Sex Res 2005; 42:113-8.

23. Yucel D, Gassanov MA. Exploring actor and partner correlates of sexual satisfaction among married couples. Soc Sci Res 2010; 39:725-38.

24. Dunn KM, Croft PR, Hackett GI. Association of sexual problems with social, psychological and physical problems in men and women: a cross-sectional population survey. J Epidemiol Community Health 1999; 53:144-8.

25. Dean J, Shechter A, Vertkin A, Weiss P, Yaman O, Hodik M, et al. Sexual Health and Overall Wellness (SHOW) survey in men and women in selected European and Middle Eastern countries. J Int Med Res 2013; 41:482-92.

26. Dennerstein L, Lehert P, Burger H. The relative effects of hormones and relationship factors on sexual function of women through the natural menopausal transition. Fertil Steril 2005; 84:174-80.

27. Eden KJ, Wylie KR. Quality of sexual life and menopause. Womens Health 2009; 5:385-96.

28. Daig I, Heinemann LA, Kim S, Leungwattanakij S, Badia X, Myon E, et al. The Aging Males' Symptoms (AMS) scale: review of its methodological characteristics. Health Qual Life Outcomes 2003; 15:77.

29. Chedraui P, Blümel JE, Baron G, Belzares E, Bencosme A, Calle A, et al. Impaired quality of life among middle aged women: a multicentre Latin American study. Maturitas 2008; 61:323-9.

30. Del Prado M, Fuenzalida A, Jara D, Figueroa R, Flores D, Blumel JE. Assessment of quality of life using the Menopause Rating Scale in women aged 40 to 59 years. Rev Med Chil 2008; 136:1511-7.

31. Rosen R, Brown C, Heiman J, Leiblum S, Meston C, Shabsigh R, et al. The Female Sexual Function Index (FSFI): a multidimensional self-report instrument for the assessment of female sexual function. J Sex Marital Ther 2000; 26:191-208.

32. O'Leary MP, Fowler FJ, Lenderking WR, Barber B, Sagnier PP, Guess HA, et al. A brief male sexual function inventory for urology. Urology 1995; 46:697-706.
33. Landis JR, Koch GG. The measurement of observer agreement for categorical data. Biometrics 1977; 33:159-74.

34. Colson MH, Lemaire A, Pinton P, Hamidi K, Klein P. Sexual behaviors and mental perception, satisfaction and expectations of sex life in men and women in France. J Sex Med 2006; 3:121-31.

35. Gonzalez M, Viáfara G, Caba F, Molina E. Sexual function, menopause and hormone replacement therapy (HRT). Maturitas 2004; 48:411-20.

36. De Lorenzi, DRS, Saciloto B. Frequência da atividade sexual em mulheres menopausadas. Rev Assoc Med Bras 2006; 52:256-60.

37. Corona G, Lee DM, Forti G, O'Connor DB, Maggi M, O’Neil TW, et al. Age-related changes in general and sexual health in middle-aged and older men: results from the European Male Ageing Study (EMAS). J Sex Med 2010; 7:1362-80.

38. Tan HM, Marumo K, Yang DY, Hwang TI, Ong ML. Sex among Asian men and women: The Global Better Sex Survey in Asia. Int J Urol 2009; 16:507-14.

39. Lawrance KA, Byers ES. Sexual satisfaction in longterm heterosexual relationships: the interpersonal exchange model of sexual satisfaction. Pers Relatsh 1995; 2:267-85.

40. Bridges SK, Lease SH, Ellison CR. Predicting sexual satisfaction in women: implications for counselor education and training. J Couns Dev 2004; 82:158-66.

41. Bouman WP. Keeping sex alive in later years. In: Tomlinson JM, editor. Sexual health and menopause. London: Royal Society Medicine Press Ltd.; 2005. p. 1-7.

42. Litzinger A, Gordon KC. Exploring relationships among communication, sexual satisfaction, and marital satisfaction. J Sex Marital Ther 2005; 31:409-24.

43. Treat SR. Enhancing a couple's sexual relationship. In: Weeks GR, Hoff L, editors. Integrating sex and marital therapy. New York: Brunner/Mazel; 1987. p. $57-81$.

44. Blanchard VL, Hawkins AJ, Baldwin SA, Fawcett EB. Investigating the effects of marriage and relationship education on couples' communication skills: a meta-analytic study. J Fam Psychol 2009; 23:203-14

45. Markman HJ, Renick MJ, Floyd FJ, Stanley SM, Clements M. Preventing marital distress through communication and conflict management training: a 4- and 5-year follow-up. J Consult Clin Psychol 1993; 61:70-7.

46. Arrington R, Cofrancesco J, Wu A. Questionnaires to measure sexual quality of life. Qual Life Res 2004; 13:1643-58.

47. Salazar A, Paravic T, Barriga O. Percepción de las mujeres y sus parejas sobre la calidad de vida en el climaterio. Rev Chil Obstet Ginecol 2011; 76:64-70.

Submitted on 30/Mar/2014

Final version resubmitted on 14/Sep/2014

Approved on 24/Sep/2014 